\title{
THE SELECTION OF STRESS COPING STRATEGIES BY UNIVERSITY STUDENTS BASED ON PRIOR COVID-19 EXPOSURE
}

\section{WYBÓR STRATEGII RADZENIA SOBIE ZE STRESEM PRZEZ STUDENTÓW Z UWZGLĘDNIENIEM WCZEŚNIEJSZEJ EKSPOZYCJI NA COVID-19}

\section{Andrei Shpakou ${ }^{1(A, B, C, D, E)}$, Liudmila Klimatckaia ${ }^{2(A, B, C, D, E, G)}$, Julia Bocharova ${ }^{2(A, B, D, E)}$, Anna Dyachuk ${ }^{3(A, B, D, E)}$, Olga Shik ${ }^{4(D, E, F)}$, Aleh Kuzniatsou ${ }^{5(D, E, F)}$}

${ }^{1}$ Department of Theory of Physical Culture and Sports Medicine,

Yanka Kupala State University of Grodno, Belarus

${ }^{2}$ Department of Social Pedagogy and Social Work, Krasnoyarsk State Pedagogical

University named after V.P. Astafiev, Krasnoyarsk, Russia

${ }^{3}$ Department of Psychology, Krasnoyarsk State Pedagogical University named after

V.P. Astafiev, Krasnoyarsk, Russia

${ }^{4}$ Department of Hygiene, Krasnoyarsk State Medical University, Krasnoyarsk, Russia

${ }^{5}$ Department of Microbiology, Immunology and Virology, Grodno State Medical University, Grodno, Belarus

Authors' contribution

Wkład autorów:

A. Study design/planning

zaplanowanie badań

B. Data collection/entry

zebranie danych

C. Data analysis/statistics

dane - analiza i statystyki

D. Data interpretation

interpretacja danych

E. Preparation of manuscript przygotowanie artykułu F. Literature analysis/search wyszukiwanie i analiza literatury

G. Funds collection zebranie funduszy

\section{Summary}

Background. The present study examined factors influencing the choice of coping strategies in response to stress caused by the pandemic. The aim of the study was the analysis of the selection of coping strategies chosen by university students stratified based on whether they had previously contracted coronavirus disease (COVID-19).

Material and methods. A variant of the COPE questionnaire was used to examine the choice of coping strategies among 876 students of Krasnoyarsk (Russia) during the lockdown. Fifteen coping strategies were assessed in 27.9\% students who had COVID-19 and 72.1\% who did not have COVID-19, taking into account sex differences.

Results. Problem-oriented and active coping strategies were common in both groups. The most common scenarios are active handling strategies (median 6.0). In both groups, respondents rarely singled out (median $\leq 4.0$ ) the use of psychoactive substances, denial of the situation, and conversion to religion. Females more often than young males used concentration on emotions as a coping strategy. Females who experienced COVID-19 refuse to believe what happened, and choose to seek social support for emotional reasons.

Conclusions. The risk of infection and the transmitted illness engendered coping strategies associated with active actions. Passive coping strategies were used less frequently. The tactics used to select appropriate coping strategies for those who have not been ill and who have recovered are similar, irrespective of sex.

Keywords: stress coping strategies, pandemic, COVID-19, stress, students

\section{Streszczenie}

Wprowadzenie. W niniejszym opracowaniu dokonano analizy czynników wpływających na wybór strategii radzenia sobie ze stresem spowodowanym przez pandemię. Celem pracy była analiza wyboru strategii radzenia sobie ze stresem przez studentów uczelni wyższych podzielonych na grupy z uwzględnieniem tego, czy byli uprzednio zakażeni koronawirusem (COVID-19).

Materiał i metody. Dokonano analizy wyboru strategii radzenia sobie ze stresem u 876 studentów uczelni w Krasnojarsku (Rosja) w czasie lockdownu, z wykorzystaniem wariantu kwestionariusza ankiety COPE. Oceniono 15 strategii radzenia sobie ze stresem u $27,9 \%$ studentów, którzy chorowali na COVID-19 i u 72,1\% studentów, którzy nie chorowali na COVID-19, uwzględniając w analizie płeć respondentów.

Wyniki. Charakterystyczne dla obu grup były strategie radzenia sobie zorientowane na problem i aktywne działania. Najczęstsze to scenariusze aktywnego radzenia sobie (mediana 6,0 ). W obu grupach badani równie rzadko wskazywali (mediana $\leq 4,0$ ) na używanie substancji psychoaktywnych, zaprzeczanie sytuacji oraz na religijne nawrócenie się. Kobiety cześciej niż młodzi mężczyźni koncentrują się na emocjach jako strategii radzenia sobie. Kobiety, które doświadczyły zakażenia wirusem COVID-19 nie wierzą $\mathrm{w}$ to, co się stało i wybierają poszukiwanie wsparcia społecznego z powodów emocjonalnych.

Wnioski. Ryzyko zakażenia i przenoszącej się choroby aktywizowały u badanych strategie radzenia sobie związane z działaniem aktywnym. Bierne strategie były stosowane rzadziej. Stwierdzono zbieżność taktyki dotyczacej wyboru strategii radzenia sobie ze stresem zarówno wśród studentów, którzy chorowali jak i tych, którzy nie przeszli zakażenia COVID-19, bez względu na płeć badanych.

Słowa kluczowe: strategie radzenia sobie ze stresem, pandemia, COVID-19, stres, studenci
Figures: 0

References: 20

Submitted: 2021 Dec 2

Accepted: 2021 Dec 27

Shpakou A, Klimatckaia L, Bocharova J, Dyachuk A, Shik 0, Kuzniatsou A. The selection of stress coping strategies by university students based on prior COVID-19 exposure. Health Prob Civil. 2022; 16(1): 57-62. https://doi.org/10.5114/hpc.2021.112364

Address for correspondence / Adres korespondencyjny: Andrei Shpakou, Department of Theory of Physical Culture and Sports Medicine, Yanka Kupala State University of Grodno, 22 Ozheshko, 230023 Grodno, Belarus, e-mail: shpakofff@tut.by, phone: +37 5297831034

ORCID: Andrei Shpakou https://orcid.org/0000-0003-4340-5211, Liudmila Klimatckaia https://orcid.org/0000-0001-8926-2901, Julia Bocharova https://orcid.org/0000-0001-8626-7977, Anna Dyachuk https://orcid.org/0000-0003-1376-9014, Olga Shik https://orcid.org/0000-0002-7000-3122, Aleh Kuzniatsou https://orcid.org/0000-0002-1348-8688

Copyright: (c) John Paul II University of Applied Sciences in Biala Podlaska, Andrei Shpakou, Liudmila Klimatckaia, Julia Bocharova, Anna Dyachuk, Olga Shik, Aleh Kuzniatsou. This is an Open Access journal, all articles are distributed under the terms of the Creative Commons Attribution-NonCommercial-ShareAlike 4.0 International (CC BY-NC-SA 4.0) License (http://creativecommons.org/licenses/by-nc-sa/4.0/), allowing third parties to copy and redistribute the material in any medium or format and to remix, transform, and build upon the material, provided the original work is properly cited and states its license. 


\section{Introduction}

Most studies of the coronavirus disease (COVID-19) pandemic assume that the threat of infection, the experience of uncertainty, self-isolation, and the transition to a forced mode of remote education, has the potential to cause stress due to the threat to health and life [1,2]. The duration, significance of the changes that the pandemic had on daily life, as well as the magnitude of the disaster, can have cumulative effects on stress [3]. The versatility of the psychological responses among humans to the pandemic can be viewed in relation to responses seen in other stress-related emergencies.

Society faces an increase in morbidity, which erodes of the usual way of life and contributes to uncertainty about the future [4]. An increase in an individual's risks associated with an unknown disease, and the use of ineffective emotional or behavioral strategies, leads to a poor handling of stressful situations, which impairs psychosomatic health [5,6]. In patients who recovered, stress can also manifest as post-COVID syndrome $[7,8]$. The SARS-CoV-2 virus is able to directly influence the activity of the central nervous system and cause psychiatric and neurological disorders affecting cognition and emotional regulation [9]. This affects the level of stress resistance in an emergency, and changes the repertoire of behavioral coping strategies used to overcome stress [10]. The choice of handling methods in the case of COVID-19 is still insufficiently covered in the modern scientific literature [11,12]. As the COVID-19 pandemic continues, its magnitude and the fact that young people are particularly at risk, the study of the aspects of coping strategies is relevant to provide appropriate and necessary psychological assistance to both those who have recovered and those who are at risk of contracting COVID-19 [13]. The social well-being and mood of students mirrors their level of well-being, social stability, and degree of satisfaction with life [14].

The aim of the study was therefore to analyze the coping strategies chosen by university students stratified based on prior COVID-19 exposure.

\section{Material and methods}

The present study enrolled 876 students at Krasnoyarsk universities (Russia) during the lockdown period. The indicators included in the study were consistent with recognition of the fact that a diagnostic confirmation of COIVD-19 has taken place. There were 244 (27.9\%) patients with COVID-19. A questionnaire was used to collect socio-demographic information (sex, age, education, etc.). The study of coping strategies amidst the pandemic was carried out using a variant of the COPE questionnaire developed by Carver et al., [15] and adapted by Rasskazova et al. [9]. This questionnaire was designed to measure situational coping strategies and dispositional styles. The degree of expression of fifteen coping strategies was determined in points ranging from two to eight. We examined: active handling strategies, planning, suppression of competing activities, restraining handling strategies, searching for instrumental and emotional social support, concentration on emotions, positive reformulation, denial, acceptance, turning to religion, the use of psychoactive substances including alcohol, humor, as well as behavioral and mental withdrawal from the problem.

All participants included in the study were informed about its objectives, methodology, and confidentiality. Access to the questionnaire was provided only if consent was obtained to participate. The Ethics Committee of the Krasnoyarsk State Medical University provided ethics approval for the study (No. N110 od 20.11.2020).

Statistical data processing was performed using the Statistica 13 PL software package. We used the nonparametric Mann-Whitney U test to examine differences between students with COVID-19 and those who had previously contracted the disease. Continuous numerical data were described as the median, along with minimum and maximum values, as well as interquartile range (IQR) were determined. The arithmetic mean (M) with standard deviation $(\sigma)$ was also used. Statistical significance was set as $p<0.05$.

\section{Results}

The mean age of the respondents was 20.0 1 1.87 years (range: $18-25$ years). COVID-19 was diagnosed in 38 (27.1\%) of 140 males and in 206 (28.0\%) of the 736 females. The distribution of sex between the two groups was similar $(p>0.05)$.

Table 1 describes differences in certain coping strategies among students stratified according to COVID-19 exposure and sex. 
Table 1. The aspects of coping strategies among students in the surveyed groups with and without COVID-19 infection, taking into account gender

\begin{tabular}{|c|c|c|c|c|c|c|}
\hline \multirow{3}{*}{ Coping strategies } & \multicolumn{3}{|c|}{ Have not had a COVID-19 infection $(n=632)$} & \multicolumn{3}{|c|}{ Recovered from COVID-19 infection $(n=222)$} \\
\hline & Males $(n=102)$ & $\begin{array}{l}\text { Females } \\
(n=530)\end{array}$ & \multirow[t]{2}{*}{$\mathbf{U}$} & Males $(n=38)$ & Females $(n=206)$ & \multirow[t]{2}{*}{$\mathbf{U}$} \\
\hline & \multicolumn{2}{|c|}{$\bar{X} \pm S D ; M e ; I Q R$} & & \multicolumn{2}{|c|}{$\bar{X} \pm S D ; M e ; I Q R$} & \\
\hline \multirow[b]{2}{*}{ Use of „sedatives” } & \multicolumn{3}{|c|}{$3.3 \pm 1.62 ; 2.0 ; 2.0-4.0$} & \multicolumn{2}{|c|}{$3.3 \pm 1.62 ; 2.0 ; 2.0-4 ., 0$} & 76123.0 \\
\hline & $\begin{array}{c}3.3 \pm 1.69 \\
2.0 ; 2-4 \\
\end{array}$ & $\begin{array}{l}3.3 \pm 1.61 ; 2.0 \\
2-4 \\
\end{array}$ & 26748 & $3.3 \pm 1.48 ; 3.0 ; 2-4$ & $3.3 \pm 1.64 ; 2.0 ; 2-4$ & 3746.0 \\
\hline \multirow[b]{2}{*}{ Conversion to religion } & \multicolumn{3}{|c|}{$3.5 \pm 1, .70 ; 3.0 ; 2.0-4.0$} & \multicolumn{2}{|c|}{$3.8 \pm 1.80 ; 4.0 ; 2.0-4.0$} & $67956^{*}$ \\
\hline & $\begin{array}{c}3.6 \pm 1.82 ; 3.0 \\
2-5 \\
\end{array}$ & $\begin{array}{c}3.4 \pm 1.73 \\
3.0 ; 2-4 * *\end{array}$ & 26329 & $3.8 \pm 1.91 ; 3.0 ; 2-5$ & $3.8 \pm 1.78 ; 4.0 ; 2-5$ & 3829.0 \\
\hline \multirow{2}{*}{$\begin{array}{c}\text { Behavioral avoidance } \\
\text { of the problem }\end{array}$} & \multicolumn{3}{|c|}{$3.9 \pm 1.50 ; 4.0 ; 3.0-5.0$} & \multicolumn{2}{|c|}{$3.8 \pm 1.48 ; 4.0 ; 3.0-5.0$} & 77035.0 \\
\hline & $\begin{array}{l}3.8 \pm 1.44 ; 4.0 \\
3-4\end{array}$ & $\begin{array}{c}3.9 \pm 1.51 ; 4.0 \\
3-5\end{array}$ & 26004 & $3.7 \pm 1.45 ; 4.0 ; 2-4$ & $3.9 \pm 1.49 ; 4.0 ; 3-5$ & 3627.0 \\
\hline \multirow[b]{2}{*}{ Negation } & \multicolumn{3}{|c|}{$4.0 \pm 1.56 ; 4.0 ; 3.0-5.0$} & \multicolumn{2}{|c|}{$4.2 \pm 1.55 ; 4.0 ; 3.0-5.0$} & 71179.0 \\
\hline & $\begin{array}{c}3.9 \pm 1.53 \\
4.0 ; 3-5 \\
\end{array}$ & $\begin{array}{c}4.0 \pm 1.6 ; 4.0 ; \\
3-5^{* *}\end{array}$ & 25947 & $3.6 \pm 1.31 ; 4.0 ; 2-4$ & $4.3 \pm 1.57 ; 4.0 ; 3-5$ & $2941.5^{*}$ \\
\hline \multirow{2}{*}{$\begin{array}{l}\text { Containment of } \\
\text { handling strategies }\end{array}$} & \multicolumn{3}{|c|}{$4.4 \pm 1.38 ; 4.0 ; 3.0-5.0$} & \multicolumn{2}{|c|}{$4.4 \pm 1.49 ; 4.0 ; 4.0-5.0$} & 69417.0 \\
\hline & $\begin{array}{c}4.3 \pm 1.44 ; 4.0 ; \\
3-5\end{array}$ & $\begin{array}{c}4.4 \pm 1.37 ; 4.0 ; \\
3-5\end{array}$ & 26215 & $4.3 \pm 1.28 ; 4.0 ; 4-5$ & $4.5 \pm 1.52 ; 4.0 ; 4-5$ & 3752.5 \\
\hline \multirow{2}{*}{$\begin{array}{l}\text { Mental escape from } \\
\text { the problem }\end{array}$} & \multicolumn{3}{|c|}{$5.3 \pm 1.38 ; 5.0 ; 4.0-6.0$} & \multicolumn{2}{|c|}{$5.2 \pm 1.52 ; 5.0 ; 4.0-6.0$} & 74024.0 \\
\hline & $\begin{array}{c}5.0 \pm 1.43 \\
5.0 ; 4-6\end{array}$ & $\begin{array}{c}5.4 \pm 1.36 \\
5.0 ; 4-6 \\
\end{array}$ & 23198* & $4.9 \pm 1.45 ; 5.0 ; 4-6$ & $5.2 \pm 1.53 ; 5.0 ; 4-6$ & 3523.0 \\
\hline \multirow[b]{2}{*}{ Humor } & \multicolumn{3}{|c|}{$5.4 \pm 1.74 ; 5.0 ; 4.0-7.0$} & \multicolumn{2}{|c|}{$5.1 \pm 1.67 ; 5.0 ; 4.0-6.0$} & $75603^{*}$ \\
\hline & $\begin{array}{c}5.6 \pm 1.94 ; 6.0 \\
4-8 \\
\end{array}$ & $\begin{array}{c}5.4 \pm 1.7 ; 5.0 \\
4-7 * *\end{array}$ & 24427 & $5.4 \pm 1.77 ; 5.0 ; 4-7$ & $5.0 \pm 1.64 ; 5.0 ; 4-6$ & 3401.0 \\
\hline \multirow{2}{*}{$\begin{array}{c}\text { Concentrating } \\
\text { on emotions and } \\
\text { expressing them } \\
\text { actively } \\
\end{array}$} & \multicolumn{3}{|c|}{$5.3 \pm 1.57 ; 5.0 ; 4.0-6.0$} & $5.1 \pm 1.69 ;$ & $.0 ; 4.0-6.0$ & 70816 \\
\hline & $\begin{array}{l}4.5 \pm 1.53 ; 4.0 \\
3-5\end{array}$ & $\begin{array}{l}5.5 \pm 1.52 \\
5.0 ; 5-7\end{array}$ & $16969 *$ & $4.3 \pm 1.77 ; 4.0 ; 3-5$ & $\begin{array}{c}5.2 \pm 1.63 \\
5.0 ; 4-7\end{array}$ & $2737.5^{*}$ \\
\hline & $5.6 \pm$ & $51 ; 6.0 ; 4.0-7.0$ & & $5.4 \pm 1.57$ & $.0 ; 4.0-6.0$ & 71064.5 \\
\hline competitive activity & $\begin{array}{c}5.5 \pm 1.67 \\
6.0 ; 4-7 \\
\end{array}$ & $\begin{array}{c}5.6 \pm 1.48 ; 6.0 ; \\
4-7\end{array}$ & 26216 & $5.3 \pm 1.50 ; 5.0 ; 4-6$ & $5.4 \pm 1.58 ; 6.0 ; 4-6$ & 3651.5 \\
\hline & 5.5 & $67 ; 6.0 ; 4.0-7.0$ & & $5.3 \pm 1.73$ & $0 ; 4.0-6.5$ & 70662.0 \\
\hline social support & $\begin{array}{c}4.9 \pm 1.74 \\
5.0 ; 4-6 \\
\end{array}$ & $\begin{array}{c}5.7 \pm 1.63 ; 5.0 ; \\
4-7 \\
\end{array}$ & $20486^{*}$ & $4.7 \pm 1.75 ; 5.0 ; 4-6$ & $\begin{array}{c}5.4 \pm 1.71 \\
5.0 ; 4-7 \\
\end{array}$ & $3091.5^{*}$ \\
\hline & $5.7 \pm$ & $64 ; 6.0 ; 4.0-7.0$ & & $5.4 \pm 1.69$ & $5.0 ; 4.0-7.0$ & $69685^{*}$ \\
\hline social support & $\begin{array}{c}5.3 \pm 1.60 \\
5.0 ; 4-6\end{array}$ & $\begin{array}{c}5.8 \pm 1.64 ; 6.0 ; \\
5-7^{* *} \\
\end{array}$ & $22212^{*}$ & $5.1 \pm 1.63 ; 5.0 ; 4-6$ & $\begin{array}{c}5.4 \pm 1.69 \\
6.0 ; 4-7 \\
\end{array}$ & 3387.0 \\
\hline & $5.9 \pm$ & $63 ; 6.0 ; 5.0-7.0$ & & $5.8 \pm 1.51$ & $0 ; 5.0-7.0$ & 71348.5 \\
\hline and personal growth & $\begin{array}{c}5.5 \pm 1.83 ; 5.5 ; \\
4-7 \\
\end{array}$ & $\begin{array}{c}6.0 \pm 1.58 ; 6.0 ; \\
5-7 \\
\end{array}$ & $22735^{*}$ & $5.5 \pm 1.59 ; 6.0 ; 4-6$ & $5.8 \pm 1.50 ; 6.0 ; 5-7$ & 3453.0 \\
\hline & $6.2 \pm$ & $45 ; 6.0 ; 5.0-7.0$ & & $6.0 \pm 1.57$ & $5.0 ; 5.0-7.0$ & 73377.5 \\
\hline $\begin{array}{l}\text { strategies } \\
\text { ste }\end{array}$ & $\begin{array}{c}5.9 \pm 1.69 ; 6.0 \\
4-7\end{array}$ & $\begin{array}{c}6.2 \pm 1.40 ; 6.0 \\
5-7 \\
\end{array}$ & 24658 & $5.6 \pm 1.76 ; 6.0 ; 5-7$ & $6.1 \pm 1.53 ; 6.0 ; 5-7$ & 3297.5 \\
\hline & $6.3 \pm$ & $42 ; 6.0 ; 5.0-7.0$ & & $6.0 \pm 1.61$ & $5.0 ; 5.0-7.0$ & $69841^{*}$ \\
\hline Planning & $\begin{array}{c}6.1 \pm 1.56 \\
6.0 ; 5-7\end{array}$ & $\begin{array}{c}6.3 \pm 1.4 ; 6.0 \\
5-7^{* *}\end{array}$ & 21432 & $6.0 \pm 1.56 ; 6.0 ; 5-8$ & $6.0 \pm 1.62 ; 6.0 ; 5-7$ & 3893.0 \\
\hline
\end{tabular}




\begin{tabular}{|c|c|c|c|c|c|c|}
\hline \multirow[b]{2}{*}{ Adoption } & \multicolumn{3}{|c|}{$5.8 \pm 1.50 ; 6.0 ; 5.0-7.0$} & \multicolumn{2}{|c|}{$5.5 \pm 1.58 ; 5.0 ; 5.0-7.0$} & 69417* \\
\hline & $\begin{array}{c}5.5 \pm 1.63 ; 6.0 \\
4.0-7.0\end{array}$ & $\begin{array}{c}5.8 \pm 1.47 ; 6.0 \\
5.0-7.0^{* *}\end{array}$ & 23948 & $\begin{array}{c}5.1 \pm 1.74 ; 5.0 \\
4.0-6.0\end{array}$ & $\begin{array}{c}5.6 \pm 1.55 ; 5.0 \\
4.0-7.0\end{array}$ & 3243.5 \\
\hline
\end{tabular}

Notes: $\overline{\mathrm{X}}$ - mean value, SD - standard deviation, ${ }^{*}$ differences between males and females between the groups, ${ }^{* *}$ indicates statistical significance at a level of $p<0.01$.

Problem-oriented and active coping strategies were common in both groups, which could be explained by the lack of ready-made solutions and methods in the uncertain period of the COVID-19 pandemic. The most common coping strategies during the pandemic situation in both groups were: positive reformulation and personal growth (an attempt to rethink a stressful situation in a positive way), acceptance, planning, active handling strategies, and using humor (median $<6.0$ ). This is consistent with what has been described by other authors $[16,17]$. Both groups used psychoactive substances, expressed denial and converted to other religion as coping strategies to a similar extent (median <4.0). The patients who recovered from COVID-19 showed a low endorsement of the following strategies: acceptance of the reality of what is happening, thinking about specific actions, developing options for strategies of behavior, and humor about the current situation. They also less often avoided looking for instrumental social support in an effort to seek advice, help or information.

\section{Discussion}

Differences in the selection of active coping strategies by students stratified based on prior COVID-19 exposure can be explained by the implementation of anti-pandemic measures, which limits normal activity in everyday aspects of life, confines people to indoor spaces, and restricts movement due to social distancing [18]. The pandemic and severe restrictive measures imposed as a result contributed to accepting the reality of what happened and assessing the importance of the problem [4]. This was reflected in minimizing denial of the situation and not focusing on behavioral and mental escapes from the problem.

In this study, female respondents, regardless of prior illness, focused on active emotional expression [15], social and instrumental support, positive reformulation and personal growth, acceptance, and mental avoidance of the problem to a greater extent compared to males. Among the females who have recovered, significant sexbased differences in refusing to believe in what happened and attempts to deny the reality were also found. The denial bias in the pandemic is a predictor of its negative consequences. In contrast, males tended to choose active handling strategies, rather than attempting to rethink a stressful situation in a positive manner. Furthermore, male respondents demonstrated a low level of concentration on emotions, and a frequent use of active coping strategies and humor.

No significant differences were found in the choice of coping strategies among males stratified according to prior COVID-19 exposure. Females without COVID-19, compared to those with a history of illness, more often resorted to active handling strategies. This included an emphasis on planning, thinking about specific actions, and developing strategies for behavioral intervention.

The coping strategies of respondents with prior illness exposure included a focus on their readiness to cope with the critical, extreme situation, but with less pronounced manifestations of active coping strategies [6]. The respondents more often noted the use of problem-oriented handling strategies; however, avoiding problems prevailed. The use of psychoactive substances among students was infrequent, which may be related to a desire for social standing, or the higher use of alcohol during the pandemic [17]. Nevertheless, this may indicate the desire to actively cope with a difficult situation $[19,20]$. Most self-isolated students spent time with their relatives and friends strengthening family ties, which may have influenced the use of psychoactive substances. Support from loved ones made it possible to overcome the difficult situation without resorting to the passive handling strategies.

\section{Conclusions}

All respondents reported experiencing a difficult situation. The risk of possible infection and coping with prior illness necessitated the adoption of active coping strategies. Those with COVID-19 chose passive handling strategies, which increases the risk for an extended duration of the pandemic and a higher incidence of postCOVID-19 complications. Respondents without COVID-19 were more likely to seek out advice, and required sympathy and understanding, as well as seeking help and additional information. In addition, rethinking and searching for positive moments in the development of a new situation, via distraction from unpleasant thoughts 
and the use of humor were common. Differences in productive activity between males and females were also minimal. However, the repertoire of coping strategies among females was broader compared to males, with a greater overall focus on emotions and expression of feelings.

\section{Disclosures and acknowledgements}

The authors declare no conflicts of interest with respect to the research, authorship, and/or publication of this article. The research was funded by RFBR, Krasnoyarsk Territory and Krasnoyarsk Regional Fund of Science (project number 20-413-242905).

\section{References:}

1. Kharitonova VI. [COVID-19: A new topic for medical anthropology]. Medical Anthropology and Bioethics. 2020; 1(19): 5-27 (in Russian). https://doi.org/10.33876/2224-9680/2020-1-19/01

2. Zoumpourlis V, Goulielmaki M, Rizos E, Baliou S, Spandidos DA. The COVID-19 pandemic as a scientific and social challenge in the 21st century. Mol Med Rep. 2020; 22(4): 3035-3048. https://doi.org/10.3892/ mmr.2020.11393

3. Kostrigin AA, Kozlova LV. [Stress caused by the threat of coronavirus infection and dominant coping strategies in youth]. The Bulletin on Pedagogics and Psychology of Southern Siberia. 2020; 4 : 33-48 (in Russian).

4. Dorosheva EA, Kudinov VN, Krutikov YD. [Influence of the COVID-19 on the time perspective]. Reflexio. 2020; 13(2): 30-43 (in Russian). https://doi.org/10.25205/2658-4506-2020-13-2-30-43

5. Burtscher J, Burtscher M, Millet GP. (Indoor) isolation, stress, and physical inactivity: vicious circles accelerated by COVID-19?. Scand J Med Sci Sports. 2020; 30(8): 1544-1545. https://doi.org/10.1111/ sms.13706

6. Khademian F, Delavari S, Koohjani Z, Khademian Z. An investigation of depression, anxiety, and stress and its relating factors during COVID19 pandemic in Iran. BMC Public Health. 2021; 21: 275. https://doi. org/10.1186/s12889-021-10329-3

7. Konjuhovskaja JE. [Stress funnel-psychological consequences for COVID-19 survivors]. Asthma and Allergy. 2020; 2: 8-12 (in Russian).

8. Jiang DH, McCoy RG. Planning for the post-COVID Syndrome: how payers can mitigatelong-term complications of the pandemic. J Gen Intern Med. 2020: 35(10): 3036-3039. https://doi.org/10.1007/s11606-020-06042-3

9. Rasskazova EI, Leontiev DA, Lebedeva AA. Pandemic as a challenge to subjective well-being: anxiety and coping. Counseling Psychology and Psychotherapy. 2020; 28(2): 90-108 (in Russian). https://doi. org/10.17759/cpp.2020280205

10. Enikolopov SN, Bojko OM, Medvedeva TI, Voroncova OJ, Kaz'mina OJ. [Dynamics of psychological reactions at the start of the pandemic of COVID-19]. Psychological-Educational Studies. 2020; 12(2): 108-126 (in Russian). https://doi.org/10.17759/psyedu.2020120207

11. Asimakopoulou K, Hoorens V, Speed E, Coulson NS, Antoniszczak D, Collyer F, et. al. Comparative optimism about infection and recovery from COVID-19; Implications for adherence with lockdown advice. Health Expect. 2020; 23(6): 1502-1511. https://doi.org/10.1111/hex.13134

12. Gemelli Against COVID-19 Post-Acute Care Study Group. Post-COVID-19 global health strategies: the need for an interdisciplinary approach. Aging Clinical and Experimental Research. 2020; 32,8: 1613-1620. https://doi.org/10.1007/s40520-020-01616-x

13. Nurunnabi M, Hossain SFAH, Chinna K, Sundarasen S, Khoshaim HB, Kamaludin K, et al. Coping strategies of students for anxiety during the COVID-19 pandemic in China: a cross-sectional study. F1000Res. 2020; 9: 1115. https://doi.org/10.12688/f1000research.25557.1

14. Tuzikov AR, Zinurova RI. [Sociology of students: a theoretical perspective and research practice]. Higher Education in Russia. 2019; 28(6): 40-51 (in Russian). https://doi.org/10.31992/0869-3617-2019-28-6-40-51

15. Carver CS, Scheier MF, Weintraub JK. Assessing coping strategies: a theoretically based approach. Journal of Personality and Social Psychology. 1989; 56(2): 267-283. https://doi.org/10.1037/0022-3514.56.2.267

16. Karáth K. Covid-19: how does Belarus have one of the lowest death rates in Europe?. BMJ. 2020; $370:$ m3543 370. https://doi.org/10.1136/bmj.m3543

17. Milman E, Lee SA, Neimeyer RA. Social isolation and the mitigation of coronavirus anxiety: the mediating role of meaning. Death Stud. 2020; 1-13. https://doi.org/10.1080/07481187.2020.1775362 
18. Bhattacharjee B, Acharya T. The COVID-19 pandemic and its effect on mental health in USA - a review with some coping strategies. Psychiatr Q. 2020; 91(4): 1135-1145. https://doi.org/10.1007/s11126-020-09836-0.

19. Kar N, Kar B, Kar S. Stress and coping during COVID-19 pandemic: result of an online survey. Psychiatry Res. 2021; 295: 1-5. https://doi.org/10.1016/j.psychres.2020.113598

20. Fernández Cruz M, Álvarez Rodríguez J, Ávalos Ruiz I, Cuevas López M, de Barros Camargo C, Díaz Rosas F, et al. Evaluation of the emotional and cognitive regulation of young people in a lockdown situation due to the Covid-19 pandemic. Frontiers in Psychology. 2020; 11: 565503. https://doi.org/10.3389/fpsyg.2020.565503 